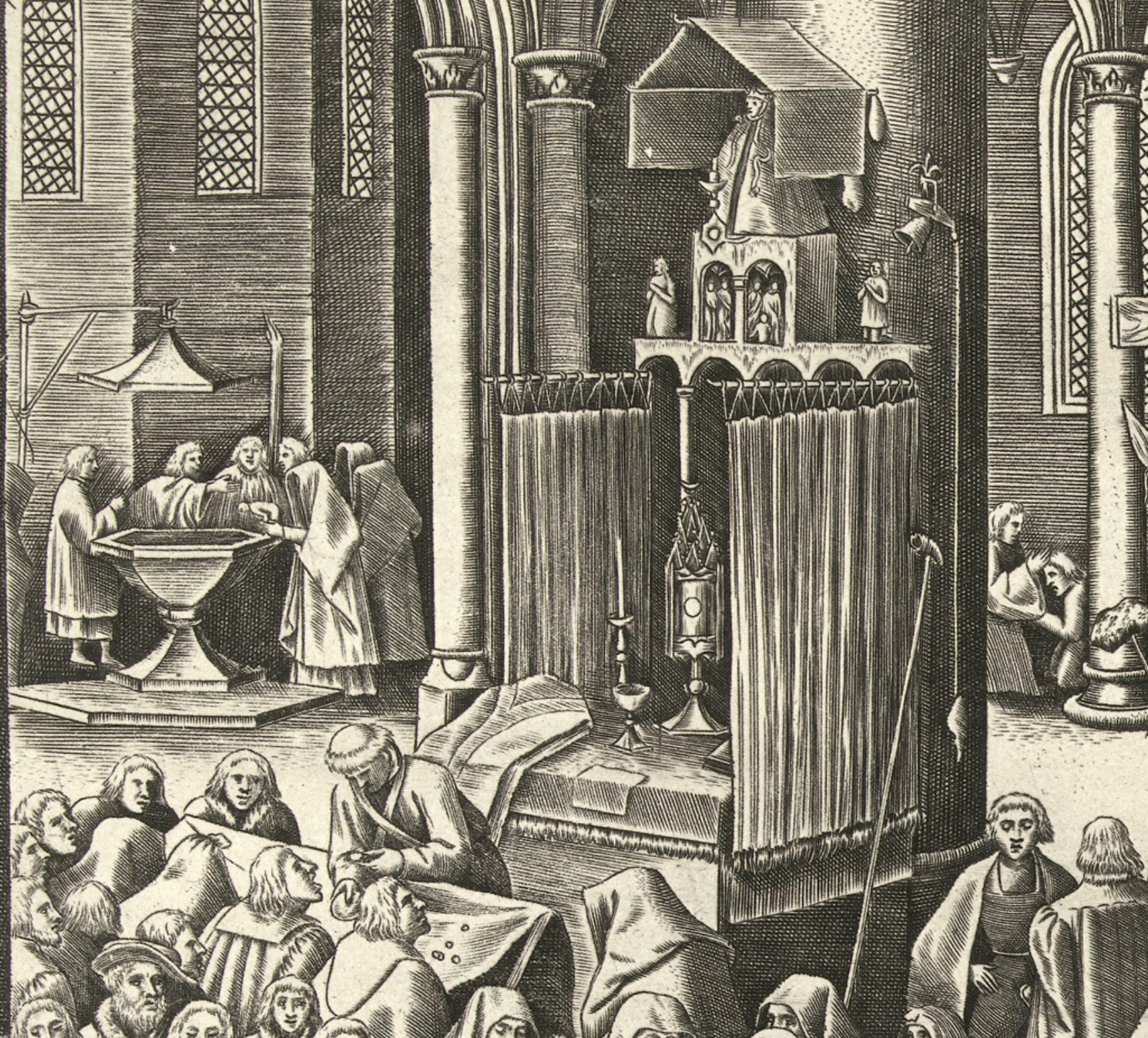




\section{Parish Liturgy}

Before it became a pilgrimage destination, Saint Leonard's church was first and foremost the seat of the parish of Zoutleeuw. As the smallest unit in the ecclesiastical hierarchy, the parish was the level on which Christians practiced and experienced religion on a daily basis. From an administrative point of view, parishes were defined as territorial entities, but they were in fact constituted by the community of its inhabitants, especially in smaller towns or rural areas. Parishioners - the churchwardens among them - had the responsibility to care for their weakest neighbors and contribute to the maintenance of the religious infrastructure. Such commitments often 'fostered a sense of belonging and ownership in the parish community'. ${ }^{1}$ Its material exponent was the parish church, often the largest stone building, and both literally and figuratively the center of the town. The church was the framework for the proper administration of the sacraments. Key moments in parishioners' lives were ritually celebrated here (fig. 80), from baptism of new-born children and their subsequent confirmation and participation in communion at Mass, over marriage, to funeral rites and burial after having received the last rites by the parish priest. $^{2}$

The stories chaplain Munters recorded in his diary show that, during the sixteenth century, many of these communal rites of passage were subjected to great pressure. Protestants started questioning and taunting not just religious images, pilgrimages and miracles, but also the core elements of the parish liturgy. Anabaptists rejected infant baptism, and dismissed the Eucharist at communion as nothing but bread. If Protestants did not openly ridicule the sacraments, they feigned belief in their propriety, for instance by accepting the last rites. How did the Zoutleeuw parish community, with its characteristic liturgical activities, react to these troublesome times? To a large extent, the administration of the sacraments remains a blind spot prior to the Tridentine reforms, as parish registers only started recording baptisms, confirmations, marriages and burials systematically at the end of the sixteenth century. This chapter discusses Zoutleeuw's parish life by focusing on two heavily debated aspects that left their traces in the churchwarden accounts: communion and
Figure 8o, detail

Philips Galle after Pieter Bruegel, Fides, 1559-156o, Amsterdam, Rijksmuseum

(C) RUBEN SUYKERBUYK, 2020 | DOI:10.1163/9789004433106_007

This is an open access chapter distributed under the terms of the CC BY-NC-ND 4.0 license. 


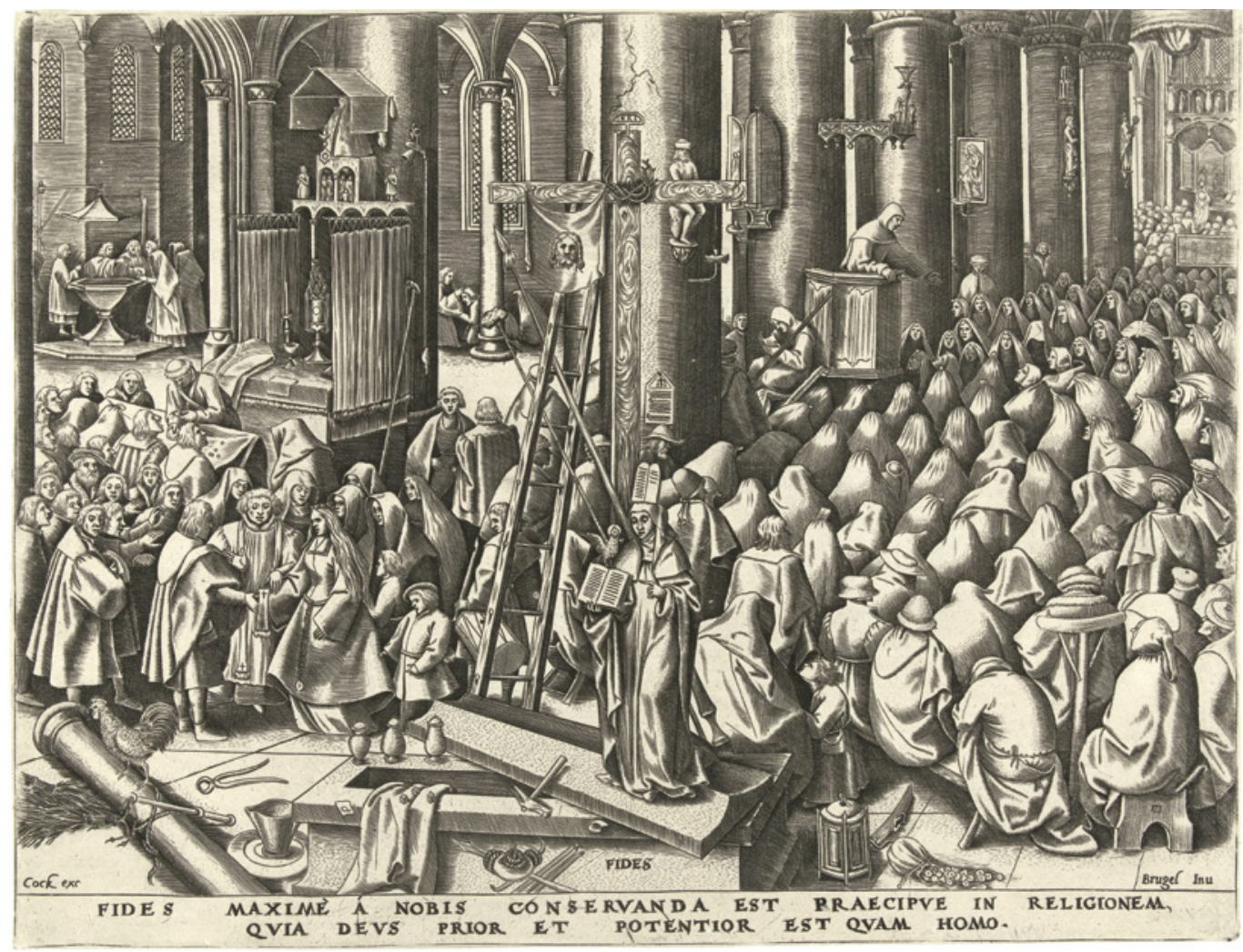

FIGURE 80

Philips Galle after Pieter

Bruegel, Fides, 1559-156o, Amsterdam, Rijksmuseum
Eucharistic devotion on the one hand, and the musical embellishment of the parish liturgy on the other.

\section{The Eucharist}

In $15^{26}$ Erasmus dispiritedly observed how the whole Western Church was being 'shaken to its very foundations'. One of the principal reasons for his religious pessimism was the universal questioning of the Eucharist. ${ }^{3}$ The Catholic celebration of this rite during Mass included the consecration of bread and wine by the priest, culminated in the elevation of the host (fig. 81), and could be followed by the communion of the attendant faithful. At the moment of the consecration, the bread and wine supposedly transubstantiate into the body and blood of Christ, thus revealing his Real Presence, which was the ground for Eucharistic miracles all over Europe. Many aspects of this Eucharistic theology and related devotions had been criticized long before the rise of Protestantism, not only by 


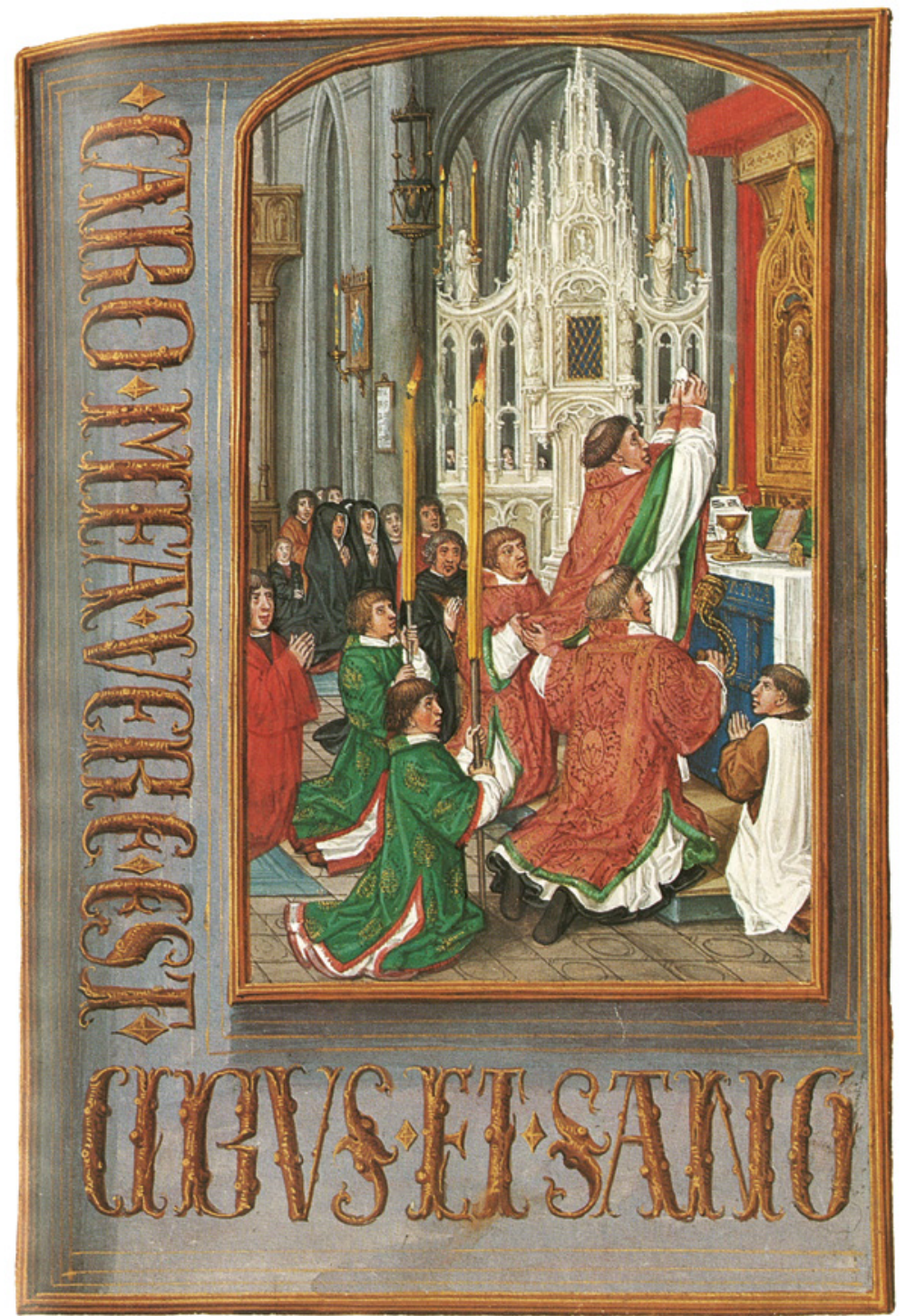

theologians, such as John Hus, but also by laypeople. In 1517, for instance, a certain Torreken van de Perre, who was by no means familiar with Protestant writings, was whipped in Oudenaarde 'for having pronounced blasphemous words against the Holy Sacrament'. ${ }^{4}$

The Protestant critique of the Eucharist intensified from the 1520 s onwards, and eventually became one of the key focal points in their attacks on the Roman liturgy. Protestant theologians developed and systematized their thoughts on the matter, and while their precise interpretations of Christ's institution of the Eucharist
FIGURE 81

Anonymous (Ghent or

Bruges), Elevation of the

consecrated host, from the

Rothschild Prayerbook,

fol. 55 , private collection 
at the occasion of the Last Supper vary greatly, they share a general rejection of the devotion as it had developed materially and physically throughout the later Middle Ages, and which was most expressively embodied by ostentatious Corpus Christi processions (fig. 82) and monumental sacrament houses such as the one in Zoutleeuw. Veluanus, for instance, explained how the institution of the doctrine of the Real Presence at the Fourth Lateran Council had given rise to 'gruesome idolatry'. Ever since, 'the bread at Mass is called God, preciously locked up, honored with monstrances, lamps, candles and high sacrament houses, and carried among images in great processions with crosses, banners, drums and all other sorts of things to

FIGURE 82

Master of James IV of Scotland, Corpus Christi procession, from the Spinola Hours, c. 1510-1520, Los Angeles, J. Paul Getty Museum, Ms. Ludwig IX 18, fol. $48 \mathrm{v}$

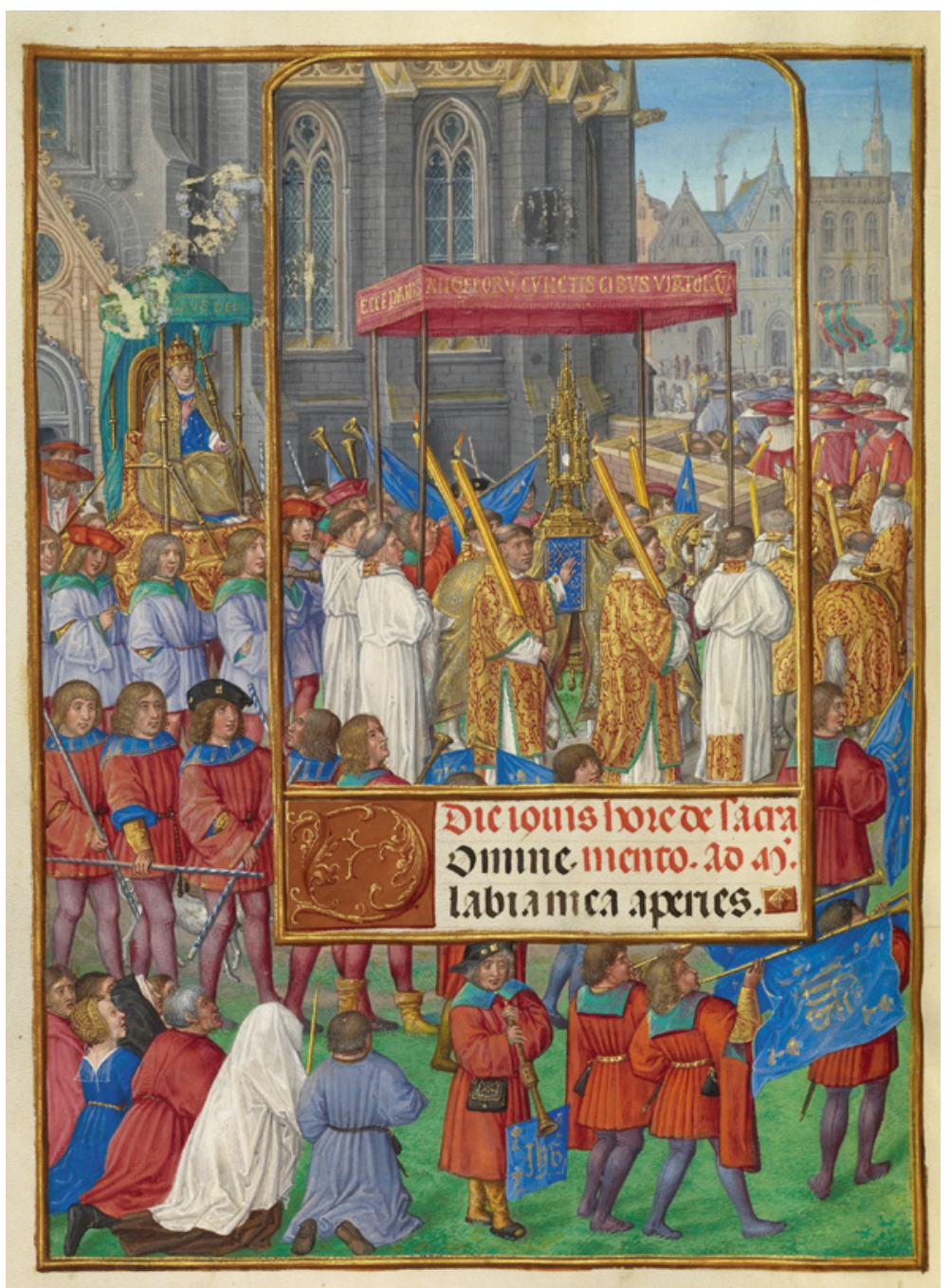


gape at, just like the pagans did to their idols (...) In sum, all over popedom the small dead bread is worshiped as the great living God' 5 As an alternative Protestant authors proposed a whole range of symbolic and spiritual interpretations of the Eucharist, one of which was expounded in Brussels by Claes van der Elst in the sermons that led to the trial against Bernard van Orley and his colleagues in 1527 (Chapter 4$).{ }^{6}$ While this congregation was generically referred to as lutheriaenen, it is clear that Van der Elst's conception of the Eucharist was very different from Luther's; Van der Elst's was much more radical and spiritual. This illustrates the variety of heterodox ideas on the subject that circulated during these early years already. ${ }^{7}$

Actions by laymen expressed this disagreement with traditional, Roman Eucharistic practices. ${ }^{8}$ In their most subtle form these actions consisted of breaking with deeply-rooted and embodied devotional conventions. For instance, in Bergues (Sint-Winoksbergen) after the Beeldenstorm, a certain Jean de Wale was convicted for misbehavior during the local Corpus Christi procession. Working as a mason on a scaffolding at the church as the Eucharist returned, De Wale had not paid due reverence by taking off his hat as one was supposed to. Others had reportedly even turned their backs to the Eucharist. ${ }^{9}$ In these days, such corporeal behavior was clearly far from innocent. More explicit were verbal attacks. In Leuven in the course of September 1566 a man was arrested for being drunk at the occasion of a procession with the Eucharist, and for having sung a taunting song when the venerated object passed over the market. ${ }^{10}$ He must have had ample inspiration, because by that time there was a rich vocabulary of mocking nicknames for the host, ranging from flour- or breadgod (meel- or broodgod) and Dieu des papistes, over Jean le Blanc or Jan de Witte, referring to its white color, to 'Melis in the crescent' (Melis in de halve maan), referring to it being merely made of flour (meel) and placed in monstrances on a holder (lunula) in the form of a crescent (fig. 83). Such names attempted to strip the sacred character from the object of veneration by reducing it to its material essence (fig. 84). ${ }^{11}$ Indeed, strategies of reduction and carnivalesque inversion of traditional values were widespread. ${ }^{12}$ In 1546 a man had to perform an amende honorable in Princenhage, near Breda, after having publicly ridiculed the Eucharist by offering a pot of mead to the celebrating priest, who was evidently using wine at that particular moment. ${ }^{13}$ And in the church of Walem, near Mechelen, somebody had shouted 'the king drinks!' when the priest consumed the consecrated wine, referring to the popular game played at the occasion of Twelfth Night. ${ }^{14}$ 


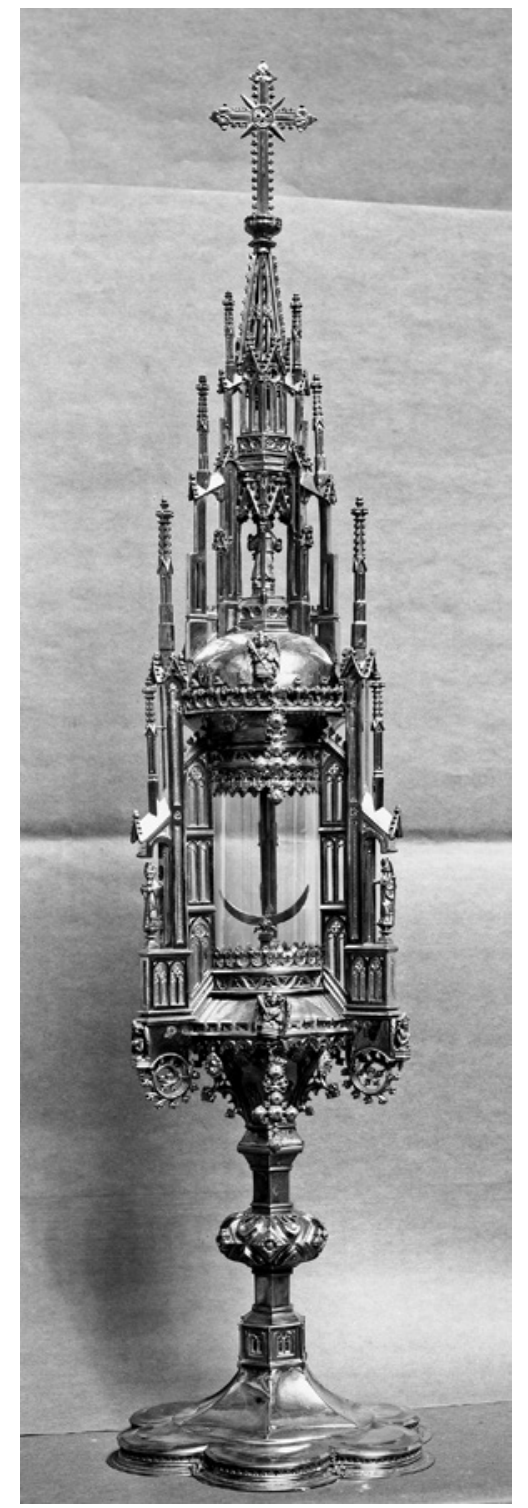

\section{FIGURE 83}

Anonymous, Eucharistic monstrance, c. 1450-1500, originally Zoutleeuw, church of Saint Leonard, stolen in 1983

(C) KIK-IRPA, BRUSSELS

The most blatant offense was of course physically attacking the Eucharist or the celebrating priest. A famous case was that of young tapestry weaver Hans Tuscaens, which even made it into the correspondence of Governess Margaret of Parma. During the Mass of the Holy Sacrament on Thursday 30 May 1566, celebrated in the parish church of Pamele, near Oudenaarde, the young man in his early twenties was noticed near the high altar, 'irreverently with a bonnet on his head' (irreventelick metten bonnette up 't hooft). At the 


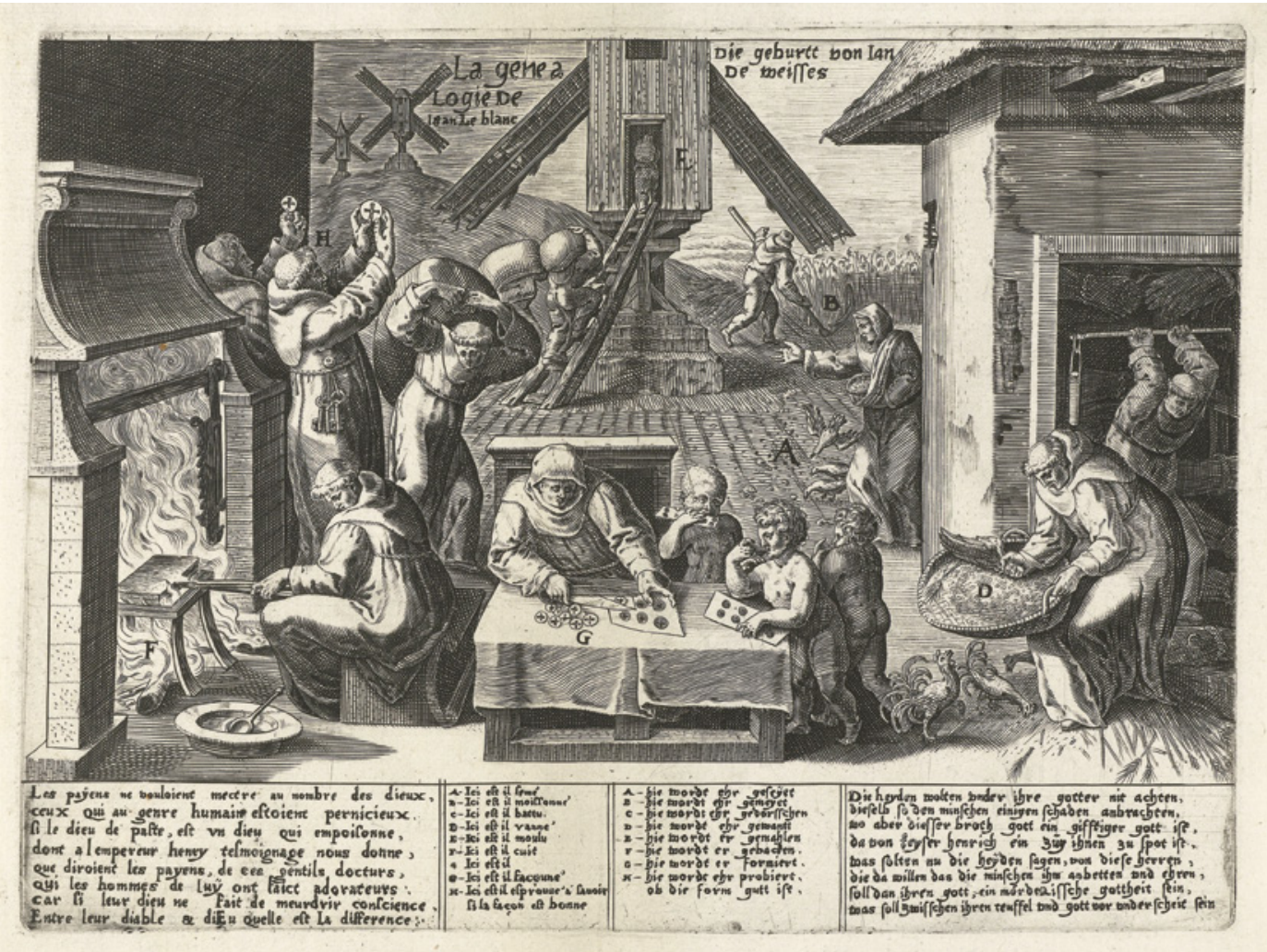

FIGURE 84

moment when the celebrating priest knelt down, holding up the consecrated host, it was snatched away from his hands by Tuscaens, who threw it to the floor. Another priest quickly picked it up in order to continue the ritual, but Tuscaens proclaimed that 'God was not in there [i.e. in the host], but in heaven' (dat God daer niet en was, maer inden hemele), that 'the idolatry had lasted far too long' (dadt zo lange duerde, dat zulcke afgoderie ghebeurende was) and that 'he was prepared to die [for his beliefs]' (dat hy bereet was daerinne te levene ende te stervene). Tuscaens was arrested immediately and soon burned alive on the market square of Oudenaarde, for which he was bravely memorialized in Protestant martyrologies. ${ }^{15}$ Interestingly, the magistracy later claimed that it was at precisely this place that the iconoclastic troubles began, with Tuscaens' family and friends inciting the people to smash images in August 1566. ${ }^{16}$ Regardless of their carnivalesque appearance, such deeds clearly were dead serious expressions of discontent.

There were stories about similar events in the broad region around Zoutleeuw as well. Aside from the tales about Anabaptists
Anonymous, La généalogie de Jean le Blanc, c. 16oo, Amsterdam, Rijksmuseum 
in Münster negating the Real Presence or the miraculous preservation of the Eucharist on the tongues of feigning believers, Christiaan Munters' diary provides ample evidence that, during the $153 \mathrm{Os}$, criticisms of traditional Eucharistic practice had gained ground in this part of the Bishopric of Liège too. Not without a certain sense of horror, he narrates multiple executions he witnessed in Kuringen, upon which occasions he learned a great deal about the convicts' beliefs, since their confessions were read out aloud. In 1534, for instance, he amazedly learned about men who 'would not believe that the priests had any power to consecrate the venerable holy sacrament'. ${ }^{17}$ At other occasions, he recorded utterances that were in line with the previously mentioned mocking nicknames for the host. Several prisoners had confessed that they did not believe in the holy sacrament, as it was 'only bread baked in the oven.' ${ }^{18}$ In early 1535 , he had even heard that there were irreverent characters who had fingered this most venerable object. ${ }^{19}$

The most notorious assessment of Eucharistic piety is probably Toussaert's. By converting the scarce data on numbers of hosts and quantities of wine, recorded in churchwarden accounts, into an estimated number of people that consumed it, he tried to calculate the number of devout parishioners actively participating in communion. ${ }^{20}$ This method was soon met with fierce criticism, since his methods of conversion were dubious and highly arbitrary. Furthermore, participation in communion was a sacramental obligation, which meant that it was not necessarily a valuable indicator of individual belief. Scholars have also remarked that frequent communion did not exist during or before the sixteenth century, and that it therefore does not provide information on the intensity of devotion. In fact, aside from the actual communion there was also a spiritual communion that did not require the consumption of the consecrated host and wine, but consisted mainly of contemplating the Eucharist. A vernacular treatise on the Mass from 1507 stated that some people 'out of humility (...) never allow themselves to go to the sacrament but hear the Mass with devotion and behold the sacrament worthily'. ${ }^{21}$

Rather than making estimations on the absolute numbers of participating parishioners, the Zoutleeuw churchwarden accounts can be used to document the actual practice and distill its evolution in the long term. The bread used for the communion was referred to as 'god's bread' (goeds broet) or 'Mass bread' (misbroet), but exceptionally also as 'hosts' (ostene) or 'bread with which one sanctifies' (broet dair men mede sacreert). ${ }^{22}$ The accounts only occasionally 
distinguish between large and small hosts, presumably meant for the consecrating priest and the laity, respectively. ${ }^{23}$ These were mostly purchased in larger cities such as Antwerp, Hasselt, Leuven, Maastricht, Mechelen or Sint-Truiden. Ecclesiastical legislation sometimes required that hosts should be made by the clergy in an almost liturgical atmosphere, but the churchwardens from Zoutleeuw simply bought them from specialized bakers, or merchants in devotionalia who also supplied pilgrim badges and pennants. ${ }^{24}$ At Easter and Christmas, and in some cases at Pentecost, lay communion also included wine, which in the accounts is referred to as monigen or, less frequently, 'to administrate the holy sacrament' (om theylich sacrament te administreren) or 'to go to the holy sacrament' (ten heyligen sacramente gaen). The wine purchased for this purpose was called 'god's wine' (gods wijn), while the participants are mostly referred to in a general way as 'the people' (tvolc), or sometimes more specifically as 'the communicants' (communicanten). ${ }^{25}$ Presumably, the congregation drank from the chalice, but people who were ill received the wine from separate cups. ${ }^{26}$ Contemporary visual sources illustrate how participants knelt down at the side or in front of the altar, behind the officiating priest (fig. 85).

Between 1546 and 1551 the purchased volumes of communion wine very suddenly quadrupled, from 23 to 85,5 quarten (resp. 31,6 and 117,5 liters). After 1555 the number dropped again to around 40 $\grave{a} 5^{\circ}$ quarten, still more than twice the original level. In $15^{6} 5^{-1567}$, it rose to an unprecedented 119,5 quarten (graph 14). ${ }^{27}$ The number of hosts is less straightforward. We do not know how long communion wafers could be preserved, but the churchwardens seem to have replenished their stock, successively buying large and small quantities (graph 15). Yet, while the maxima continued to rise to a peak of 25.900 hosts in 1548 , the minima did not decline, which is suggestive of an overall upward trend, with a slight drop after the middle of the 155 os. Hence, both datasets suggest a similar slight growth throughout the middle of the sixteenth century, which accelerated quite suddenly around $155^{\circ}$. What do these increasing quantities of communion wafers and wine mean? Do they straightforwardly signal an increased participation in communion around 155 ? ?he Zoutleeuw parish might possibly have been subjected to some organizational changes, but the evidence is unclear, and the documented depopulation of both town and countryside makes it highly unlikely that such developments would account for a quadrupling of the amount of communion wine. ${ }^{28}$ Thus, if there was no significant increase of the number of potential communicating parishioners, there are 


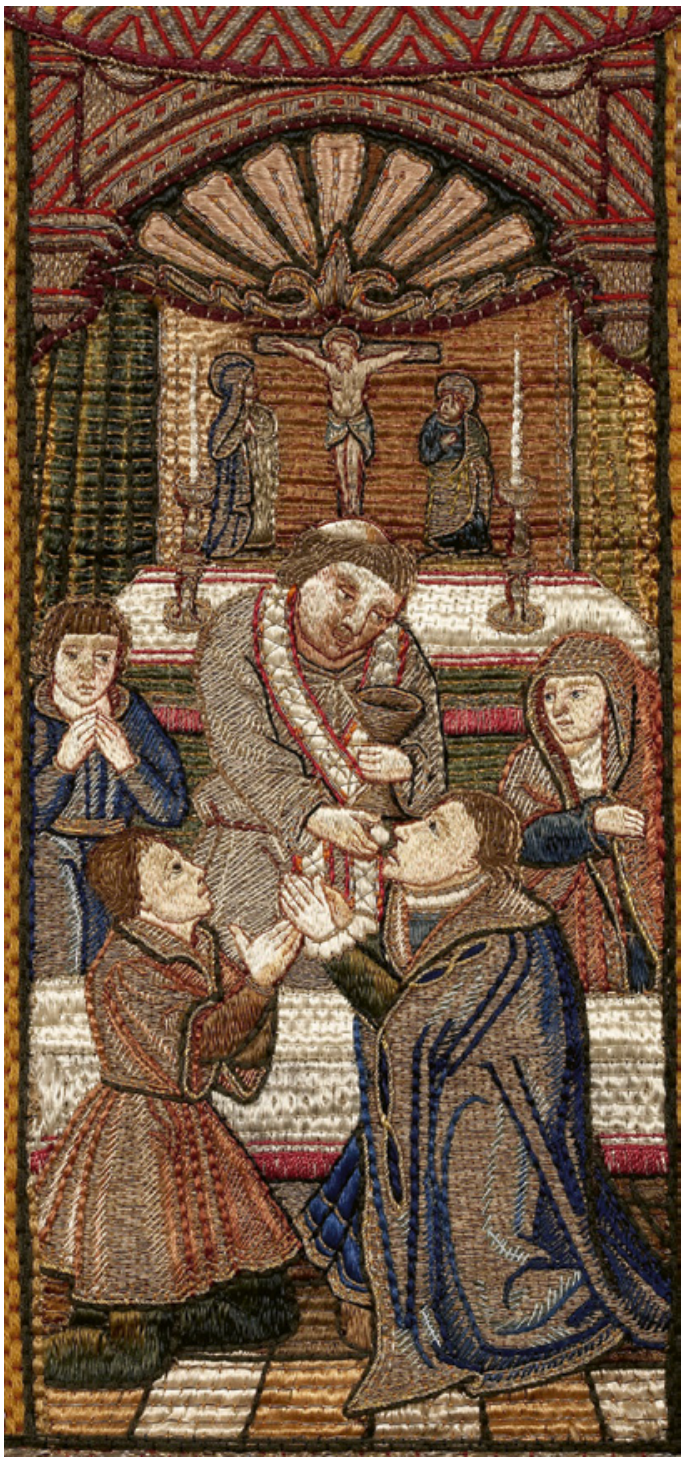

FIGURE 85

Anonymous,

Communion, scene on the orphrey of a chasuble, c. 1530 , Zoutleeuw, church of Saint Leonard (C) KIK-IRPA, BRUSSELS

three possible explanations: a greater number of parishioners participated in conventional communions, there were more occasions for communion per year, or a combination of both.

The actual number of participating parishioners is impossible to determine, but documented changes in the practice strongly suggest that lay communion happened or at least was proposed more frequently throughout the year. From 1556 onwards, the accounts suddenly started recording sums of money that were offered 'on 
the table for the wine', referring to a communion rail or bench. ${ }^{29}$ Indeed, temporary precursors to what would later develop into the elaborate and permanent baroque communion rails were already in use in the Low Countries well before (figs. 8 o \& 86$).{ }^{30}$ For example, an entry in the account from 1540 of Antwerp's church of Our Lady documents the acquisition of 'six cloths to lay on the tables where the wine is given in the communing of the people'. ${ }^{31}$ Similarly, the range of duties of the carilloneur of the church in Tiel (Guelders) included the preparation and decoration of 'the bench where one receives the wine and bread'. ${ }^{22}$ And in $1554-1555$, the churchwardens of Saint Nicholas' church in Diksmuide commissioned a new table from a local carpenter for that very purpose. ${ }^{33}$ It is unclear whether it was common to offer money for the received communion wine in Zoutleeuw before 1556 . However, while the earliest recordings only

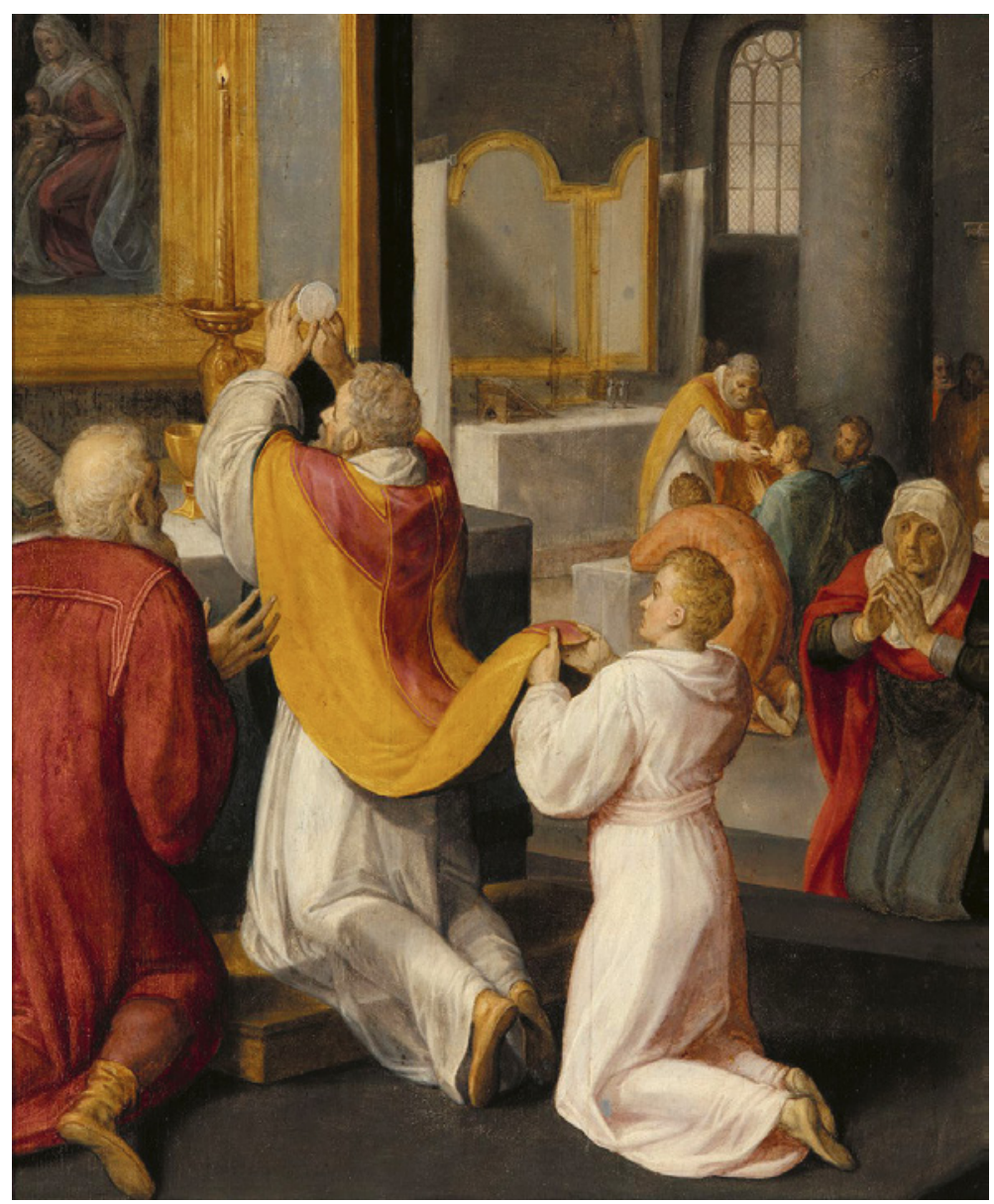

FIGURE 86

Frans I Pourbus, Mass and communion, from the Cycle with the history of Saint Andrew, 1572, Ghent, cathedral of Saint Bavo (C) LUKASWEB - ARTS IN FLANDERS VZW 
mention this habit at the occasion of Easter and Christmas, other holidays soon followed. ${ }^{34}$ From 1561 onwards, offerings for wine are recorded on Candlemas, and from at least 1566 onwards also on All Saints' Day. From at least $155^{1}$ onwards, wine was offered at the occasion of the sale of indulgences. ${ }^{35}$ The amounts of money offered at the occasion of communion at Easter and Christmas also show an upward trend throughout the period under consideration.

In sum, the evidence suggests a continued enthusiasm for the sacrament of communion, which markedly intensified around $155 \mathrm{O}$. Remarkably, this actually predates the decisions taken at the Council of Trent. At its thirteenth session in 1551, the Council had reaffirmed the doctrine of the Real Presence, propagating a combination of sacramental and spiritual communion, and urging to 'communicate [in a sacramental way] every year, at least at Easter'. However, it was not until 1565 that these decrees were officially published in the Low Countries. ${ }^{36}$ Hence, the developments at Zoutleeuw can by no means be considered an early implementation of the Tridentine decrees. Yet, vernacular devotional treatises had already promoted similar tenets. The Mechelen Friar Minor Frans Vervoort (d. 1555), for example, had urged his readers to 'often go to the holy sacrament [i.e. communicate] with burning desire'. ${ }^{37}$ It is unclear whether the developments in Zoutleeuw were the result of an initiative from the clergy or from increasing demands from the part of the congregation. Still, similar trends have been noted elsewhere. In Lier the monetary offerings for the communion wine rose between 1548 and 1578 , and this was also the case in Turnhout between 1533 and $1569 .{ }^{38}$

Participation in communion is evidently not the same as Eucharistic piety, but both are still ritually related expressions of the same theological principles that were at the heart of the religious debate. While the increasing frequency of proposed communion would foster actual, sacramental communion in the community of Zoutleeuw, other facilities, such as the newly built sacrament house, would stimulate parishioners in their desire to communicate spiritually. Saint Leonard's church was also home to a foundation of Lauds of the Holy Sacrament (heylich sacraments loff or laudes venerabilis sacramenti). The raison d'être of these foundations - referred to in a 1468 document from Breda as a habit in the most important Brabantine churches - was the adoration and benediction of the Corpus Christi with laudatory songs, music, and candlelight. For this purpose, the Eucharistic monstrance was temporarily taken out of the sacrament house and shown to the congregation (fig. 87). ${ }^{39}$ 


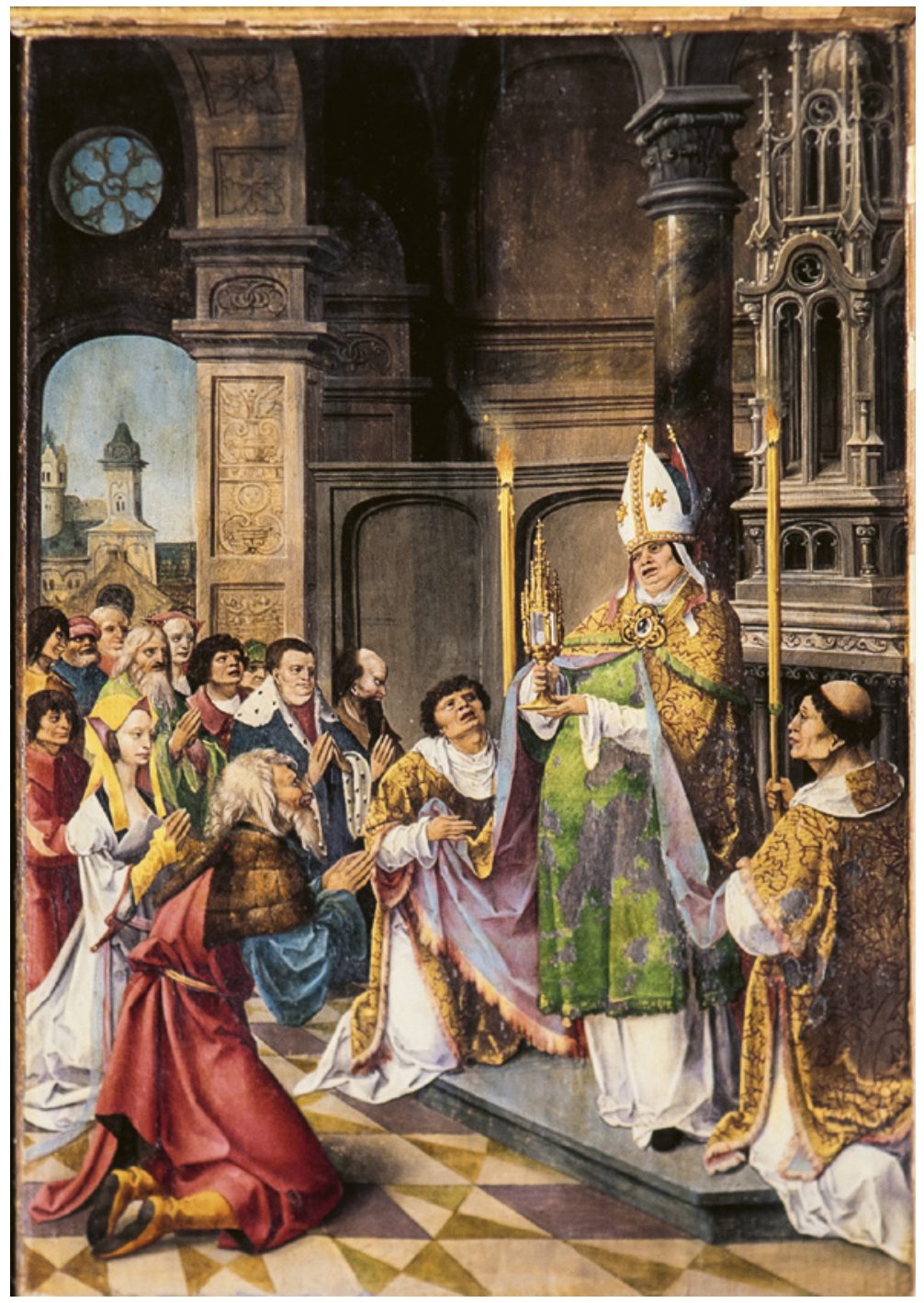

Financial support for such celebrations was often provided by confraternities, such as in Antwerp. This was not the case in Zoutleeuw, however. ${ }^{40}$ The foundation was managed by two lay wardens ( $\mathrm{mom}$ baers), but it is never called a gulde or bruederschap, nor do the preserved accounts mention any members or subscription fees. ${ }^{41}$ Originally, it must have been a private foundation, independent from both the fabrica ecclesiae and the collegiate chapter, which grew over time through donations and arrangements. Documented as early as 1458 , it was incorporated in the fabrica ecclesiae in $1555 \cdot{ }^{42}$

\section{FIGURE 87}

Anonymous (Antwerp),

Adoration of the Holy

Sacrament, from the Passion altarpiece, first opening, upper right wing, 1516, Västerås, Cathedral (C) SWEDISH HISTORY MUSEUM 
FIGURE 88

Adriaen van Overbeke and workshop, Adoration of the Holy Sacrament, from the Passion altarpiece, first opening, upper central panels, installed 1523 , Schwerte, Sankt Viktor PHOTO: DIETRICH HACKENBERG
The service took place weekly, together with the Mass of the Holy Sacrament after the matins on Thursdays. The foundation provided yearly payments to the chapter for the service to be celebrated as a solemn Mass: before Mass, the verse Tantum ergo sacramentum was sung, followed by Genitori genitoque after Mass. Both were parts from Thomas Aquinas' hymn Pange lingua, written for the Feast of Corpus Christi. ${ }^{43}$

The foundation's accounts document its evolution, recording expenses as well as income from bequests, an offertory box in the church, and occasional collections in town. ${ }^{44}$ Between 1537 and 1543 , both the revenues and expenses increased quite suddenly, suggesting that there must have been an increasing number of bequests and services. For example, torches carried by children - a possible embellishment of the lauds ceremony often provided for by private funding - were only documented for the first time in $1537 . .^{45}$ In 1539 , the foundation bought a new black velvet cope in Antwerp. At the occasion of the weekly adoration of the Holy Sacrament, the monstrance was shown only briefly to the people by the parish priest, but from 1533 onwards, the churchwarden accounts also document a long-lasting exposition of the Holy Sacrament at Pentecost and Corpus Christi, possibly lasting a whole day (figs. 8 o \& 88, and p. 168). For this purpose a carpenter was paid for the 'putting in and out' of the monstrance, presumably being commissioned with the production of a temporary structure for the extended display. In 1547 , for instance, Joes van der Gheeten was paid for a 'table on which the Holy Sacrament rests.' 46

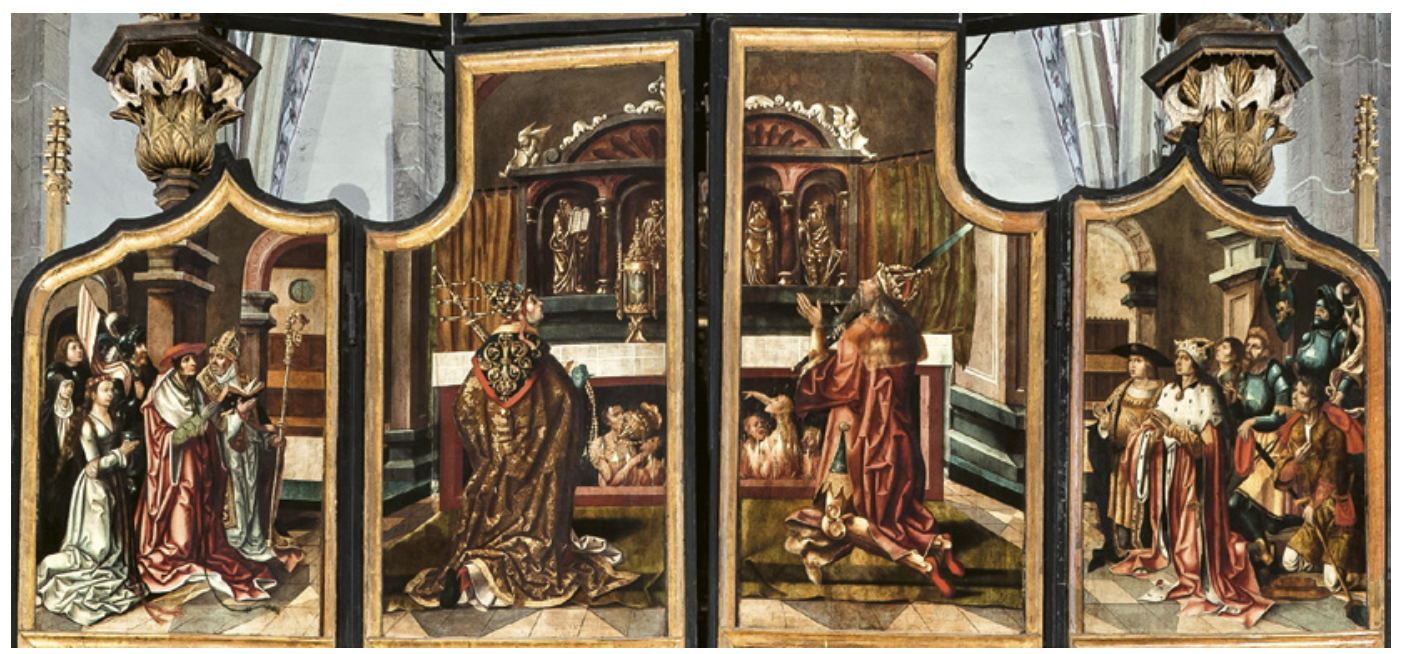


While Eucharistic devotion became highly controversial after 1520 , it clearly did not lose its appeal in Zoutleeuw, nor elsewhere in the Low Countries. The cults of the Miraculous Hosts of Brussels and Leuven both enjoyed renewed popularity (Chapter 4), and the confraternity of the Holy Sacrament in the church of Saint Nicholas in Brussels also benefited from a large and constant membership throughout this period, with a number of around 100 members. ${ }^{47}$ We do not know anything about the attendance at Zoutleeuw's yearly Corpus Christi procession, but judging by the accounts, it must have remained in vogue. In Oudenaarde for instance, such events continued to attract huge crowds from inside and outside town, and in Liège the number of processions even increased. ${ }^{48}$ Interestingly enough, similar increasing numbers of processions in France have been linked to Protestant reproaches. ${ }^{49}$ It would be uncareful to interpret this as evidence of a causal relationship at this stage, but at the very least, these examples reveal a stubborn continuity rather than a radical change.

\section{Musical Embellishment}

The Eucharist came to be the main subject of Protestant critique on the Catholic liturgy, but it was definitely not the only aspect of the Roman Mass Protestants took offense at. The music performed during the rituals was another bone of contention. All different kinds and functional types were questioned, both instrumental and vocal, from Gregorian plainchant to the most elaborate polyphony. Just like many of the reformers' other critiques, they originally came from an older tradition. In the later Middle Ages a number of church councils had forbidden polyphonic music, and Savonarola strongly condemned it, together with other worldly vanities. Erasmus' notorious critiques reveal the reasons of this relatively broad-fronted opposition to melismatic decoration. From at least 1519 onwards, he regularly uttered his profound dissatisfaction with what he called unintelligible 'musical neighing' (musicus hinnitus)..$^{50} \mathrm{He}$ considered the elaborate and ornamental character of late medieval polyphony unnecessarily distractive from the text that was sung, i.e. the word of God. This was the ground for the Protestant's dissatisfaction. Much like the prevalent critiques on images and the Eucharist, critics reduced the music to its physical essence. Karlstadt, for instance, claimed that plainchant was 'merely sound, nothing else'. Yet, their respective positions differed strongly, as did the consequences they 


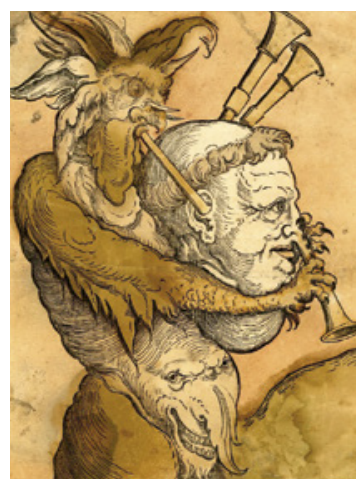

FIGURE 89

Erhard Schön, The devil's

bagpipes, c. 1530, London,

British Museum drew from their observations. Here as elsewhere, Luther arguably took the most moderate position, whereas Calvin and Zwingli held the most radical opinions. While in 1522 Luther replaced Gregorian chant by congregational hymns, a year later Zwingli devoted himself to completely abolish all church music. ${ }^{51}$ In the Low Countries, Veluanus demanded absolute clarity of text, stripped of all superfluous acoustic ornament (zyraet). In order for all to understand, prayers were to be said in the vernacular rather than murmured in Latin and they were not to be 'disturbed by useless Gregorian choral singing'. 52

Just how inextricably the clergy was connected to music in the minds of Protestants is demonstrated by the former being represented as the devil's bagpipes in widely distributed satirical prints (fig. 89). Music is also given a leading part in The Mass of the hypocrites, another woodcut that circulated in the Low Countries around 1566 , showing a satirical depiction of the Mass, with the clergy represented as foxes (fig. 9o). On the right side, a fox plays the organ, while on the left a choir sings from a songbook on a lectern. In the upper left corner, another fox rings the bell at the occasion of the consecration. The anti-Roman cartoonist clearly considered liturgical music - both vocal and instrumental - a quintessential characteristic of papist hypocrisy. It is in this context that the massive destruction of organs and liturgical songbooks during the Beeldenstorm should be understood, as they were the material embodiments of this essential yet thorny aspect of the traditional liturgy. ${ }^{53}$ In Tournai, for instance, one man was condemned by the Council of Troubles for having 'torn down and broken the organs in the church of Saint Brice, saying that they have made God dance enough musettes', the latter being a traditional pastoral dance to the sound of bagpipes. ${ }^{54}$ Once more, such remarks linked the celebration of the liturgy to devilish bagpipes, an instrument traditionally associated with lust.

Nevertheless, despite all these dismissive remarks, music was of vital importance to Protestant rituals and actions as well. However, contrary to the elaborate musical arrangements of the Latin liturgy, theirs was mainly vocal music, with texts in the vernacular. Many indexes of prohibited books that had been published in the preceding years - first by secular authorities, and in 1559 for the first time by the Church of Rome - contained songbooks. ${ }^{55}$ Doubtlessly, many consisted mainly of satirical songs, but by the early 1540 s the Protestant practice of congregational singing had also stimulated the production and distribution of musical arrangements of the psalms, as well as their translation from Latin into the vernacular. ${ }^{56}$ 


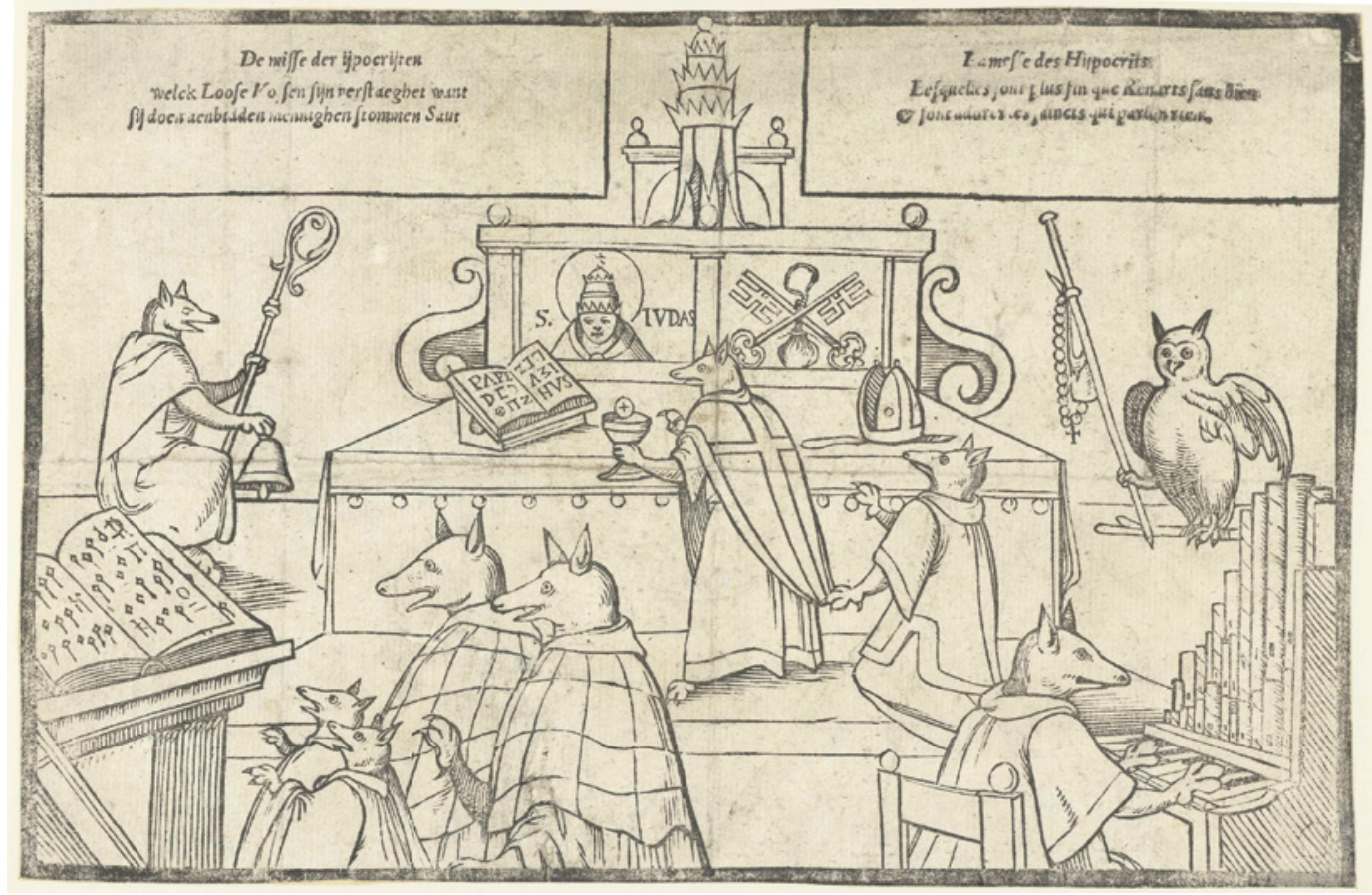

FIGURE 90

The most famous reworkings are those by the French poet Clément Anonymous, De misse der ijpocrijten/La messe Marot, some of which Calvin himself had collected and published as Aulcuns Pseaulmes (1539). Subsequently, they also came into use in Reformed services. Later, in 1541 and 1543, Marot published some other adaptations himself, which were soon put on the index. At the very same time, there was also a full translation available in Dutch, probably by the Utrecht nobleman Willem van Zuylen van Nijevelt. These were arranged on the melodies of popular and at the time widely-known songs, and published as Souterliedekens in Antwerp in $1540 .{ }^{57}$ Other translations of Marot were published in 1565 and 1566, by Ghent artist Lucas d'Heere and Petrus Datheen respectively. They were both titled De Psalmen Davids.

The performance of these collections and their adaptations played an increasing role towards the Wonderyear. An inquiry into the events at Brandwijk (near Dordrecht) revealed that 'the parish priest had come into the church, ascended the pulpit without stole or cope, during which Dutch psalms were sung and after which the priest delivered his sermon in such way'. ${ }^{58}$ They were also a crucial element in the so-called hedge-preachings (hagenpreken). On 7 July 1566 in Antwerp, for instance, many people went to these sermons, armed with weapons as well as with Marot's psalms, which 
were reportedly for sale in Ghent for a small price. ${ }^{59}$ It is overtly clear that the singing of these psalms by the interested audience, both during and after the sermons, was considered highly provocative. At several instances the crowds walked in battle-array through cities while singing psalms. For example, a number of weeks before the actual outbreak of the Beeldenstorm, a singing group of Calvinists came into the city of Ieper and marched to the town hall. ${ }^{60}$ The singing continued throughout the iconoclastic acts as well. In Antwerp, they immediately preceded the destructions in the cathedral, which led an observer to remark that Marot's psalms 'have always served as foreboding and countersign at all their [the Calvinists'] ventures'. ${ }^{61}$ And the chamber of rhetoric in Den Briel reportedly held a mock trial against images and liturgical books, which they then burned while singing psalms and satirical songs. ${ }^{62}$ Hence, it is not surprising that singing these songs was also considered a major crime by the Council of Troubles. In Cassel, for example, a man was condemned for having 'scandalized everybody by publicly singing the forbidden psalms' and in Tournai somebody was suspected of having sold psalms and forbidden books. ${ }^{63}$

Bunderius disdainfully rejected Protestant congregational singing as 'the mooing of cows, or the bleeting of sheep'. He contended that only the ornamental, liturgical chant (cirage) could 'inspire devotion in the people. ${ }^{64}$ But music would not be a major issue at the Council of Trent. The decrees in which it is discussed only mention it in passing, and the only guidelines were rather limited and vague in terms of content. Much like in the decrees on images, it tried to do away with all lascivious and impure elements, but specific directions on the actual execution of the traditional repertoire were left for the bishops to decide during provincial synods. ${ }^{65}$ Nevertheless, the lay appropriation, reworking and translation of sacred songs into the vernacular, as well as their performance in contexts outside the liturgical confines of consecrated church buildings, was clearly considered unacceptable in the eyes of the Catholic authorities.

Devotional songs in the vernacular certainly existed in civic or paraliturgical contexts, but the musical embellishment of liturgical services was first and foremost a task of the clergy: in smaller parish churches, it was performed by the officiating priest, whereas in collegiate churches such as Saint Leonard's, the whole chapter was supposed to perform the prayers at the canonical hours. ${ }^{66}$ Schoolmasters were often called in with their pupils as well, and the common musical background for the singing of these different voices was provided by the organ player, who was mostly appointed. Evidently, 
larger churches with a higher number of active clergymen had more potential to perform elaborate musical services, but a lot also depended on foundations and patronage. At many places, ensembles of professional musicians under the direction of a zangmeester were erected with secular funding, either private or by confraternities. Contrary to many clergymen, these singers were schooled in the newest musical developments, and thus were able to perform highly complex arrangements. In absence of any preserved musical repertoire, it is often very difficult to establish whether these musical arrangements were polyphonic or not, but it is generally assumed that Gregorian chant was sung at normal services, whereas polyphony was reserved for important feast days or special occasions, when external musicians were hired. For instance, this was still the case in the Antwerp parish churches in the second half of the sixteenth century. ${ }^{67}$ Fabricae ecclesiae were important consumers of religious music, because they paid the musician's wages and were responsible for both the acquisition and maintenance of musical books and instruments. ${ }^{68}$ As a result, the Zoutleeuw churchwarden accounts contain important information on musical performances.

Professional musicians hired for the liturgy appear only rarely in Zoutleeuw's accounts before the middle of the sixteenth century, and there is no evidence of the town having a reputation for exceptional musical education. Yet, around the middle of the century, there are a number of indications which suddenly signal an increasing musical adornment of the liturgy. Since the mid-fifteenth century, the Mass performed at the feast day of Saint Leonard (6 November) was solemnly celebrated with a priest, deacon and subdeacon, and musical embellishment of the services was usually provided by the chapter school choir, accompanied by organ music. Apart from some exceptions in the 1480s (Chapter 2), no external, professional musicians were hired at this occasion, suggesting that the singing was relatively uncomplicated. This is corroborated by the church's graduals, commissioned in 1487, in which all musical settings - including those for the liturgy of Saint Leonard - are in Gregorian plainchant (fig. 91). ${ }^{69}$ However, this changed over the course of the 1540s, when professional singers under the direction of an independent zangmeester were added to the Mass for Saint Leonard. The accounts confirm that this novelty nearly doubled the budget for the celebrations, and that payments were made by order of the civic authorities. Directed by Master Jan den sangmeester, the singers were hired from other towns in the region. In 1547 the group was based in Diest, whereas in 1550 they hailed from Sint-Truiden. ${ }^{70}$ Nothing is known about 


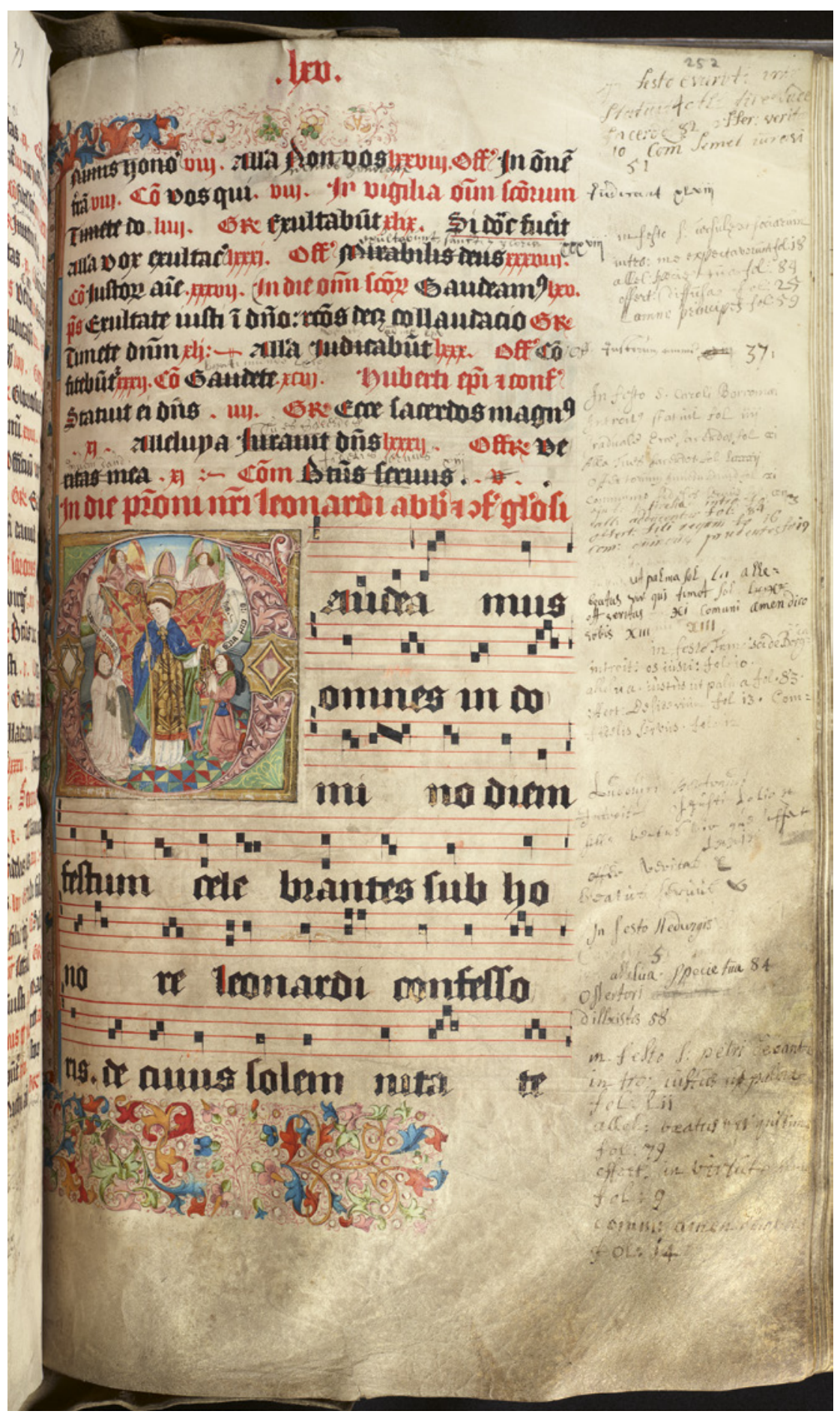

FIGURE 91 Chant for the feast of Saint Leonard in the Zoutleeuw gradual, 1487-1494, Brussels, KBR, Ms. 21132, Sanctorale, fol. 65 
the latter, but the group from Diest had a wider regional reputation, and there is ample evidence that this town was a relatively important musical center in the later fifteenth and sixteenth centuries. Singers from Diest are mentioned in Kuringen and other important churches in the Duchy of Brabant that had impressive musical ensembles, including the churches of Our Lady at Bergen op Zoom, Breda and 's-Hertogenbosch. ${ }^{71}$ Hence, the fact that the authorities from Zoutleeuw were able to hire singers from Diest is indicative of their ambition.

The musical arrangements must have been quite elaborate indeed. The accounts reveal that the musicians helped sing the Mass at Saint Leonard's day, but from at least 1557 onwards, celebrations also included lauds (loff).${ }^{72}$ Such ceremonies were extra-liturgical devotional services with particular musical attention, whose performance varied from place to place, and often depended on funds that were available. These services included antiphons and hymns, often accompanied by organ music, but also, and most importantly, polyphony. ${ }^{73}$ This appears to have been the case in Zoutleeuw as well. Saint Leonard's Mass is known to have been sung in discant in the late 1540s, for which purpose a new large songbook 'in discant' (van duyskant) was commissioned from Master Jan den sangmeester in $1548-1549 \cdot{ }^{74}$ The term refers to a polyphonic singing technique in which one or more upper voices were added as counterpoint to a plainchant part. ${ }^{75}$ This was by no means a new phenomenon in the mid-sixteenth century, but it was still considered a marvelous thing. In 1545, for instance, chaplain Christiaan Munters deemed it worthy of mention in his diary that a whole Mass was sung in discant in the church at Kuringen. ${ }^{76}$ The addition of extra, melodious layers to pre-existing musical structures was described as 'ornament' by contemporaneous observers, including both Veluanus and Bunderius. ${ }^{77}$

The polyphonic enhancement of the traditional Mass for the church's patron saint must have been a considerable ornamental addition to this highlight in the Zoutleeuw liturgical year. In fact, this was related to broader musical investments in Saint Leonard's church in precisely these momentous years. In 1556 , Merten van Wilre - the donor of the sacrament house - provided the fabrica ecclesiae with money to have lauds sung on five evenings a week: on Sunday for the Holy Trinity, on Tuesday for Saint Anne, on Wednesday for the Holy Name of Jesus, on Friday for the Holy Cross and on Saturday for Our Lady. ${ }^{78}$ Musical embellishments were also at the core of the weekly Lauds of the Holy Sacrament, which had expanded significantly between 1533 and 1537. From 1559 onwards, a group of singers 
also received a yearly pay at the occasion of the feast of Saint Cecilia (22 November), the patron saint of musicians. ${ }^{79}$ Their precise assignment is unknown, but the accounts suggest that they sang the upper voices in discant, just like on Saint Leonard's day. ${ }^{80}$ The contemporaneous acquisition of a number of songbooks is undoubtedly related to these polyphonic novelties, suggesting that new works and arrangements were added to the existing repertoire. In most cases, the precise nature of these musical collections remains unclear, as they were merely referred to as sancboeck. ${ }^{81}$ However, one entry of September 1559 reveals that Willem van Dalem, then dean of the collegiate chapter, was commissioned to write a Mass in muesycke, a term that unambiguously referred to polyphonic arrangements. ${ }^{82}$

The heightened attention for musical performances was also reflected in the infrastructure. For instance, in February 1555 a new lectern for singers was made. ${ }^{83}$ The clearest example of the improvement of musical infrastructure can be found in the expenditures for the organ. From 1508 onwards, the salary of the organ player had been fixed at 400 stuivers a year. In 1557, however, it was quite suddenly increased to $5^{20}$ stuivers. It is possible that this had had something to do with a more general increase in wages throughout the sixteenth century, but it is was most certainly also linked to a number of investments in the organ itself. Sensitive to climatic changes, it was a near-constant debit item. It had to be tuned on a regular basis, the leather bellows had to be greased or repaired, and the instrument had to be furnished with iron locks or wooden doors. By the middle of the sixteenth century, at least two different instruments were in use in Saint Leonard's church: a relatively small, positive organ on the rood loft (posetyff opten ocksale) and a great organ high up against the church wall (referred to as den organen metten stoele or tgroet orghelwerck). ${ }^{84}$ The latter was probably located above the church doors in the eastern wall of the southern transept (fig. 4), where it could be used for the celebrations in the presbytery, as well as in Saint Leonard's chapel. ${ }^{85}$

This great organ in particular underwent some important reparation and extension campaigns, led by the most renowned organ manufacturers in the Low Countries. ${ }^{86}$ In the 1470 s and 1480 os the works had been supervised by Jan II van Aren, who was commissioned to reform the organ for a sum of 45 Rijnsgulden. ${ }^{87}$ Between 1501 and 1508, the instrument was rebuilt by Daniël van der Distelen (doc. 1472-1508), based in Antwerp and Mechelen but active in the most important churches in the whole Duchy of Brabant. His salary of 55 Rijnsgulden again suggests a fundamental intervention. ${ }^{88}$ This 
was followed by some minor reworkings by Anthonis Toers (doc. 1525-1555) from Tienen, such as in 1525, when a set of eighteen pipes was added to the instrument, and $1533-1534 .{ }^{89}$ However, the most important investments took place in the 155 os. In 1554 and 1555 , Toers installed a set of new pipes and a new roeperken, after which the whole organ was repaired, cleaned and tuned..$^{90}$ Subsequently, the churchwardens approached Nicolaas Niehoff (c. 1525-c. 1604), a member of a dynasty of organ builders active all over the Low Countries and up to Hamburg and Lüneburg. His intervention is merely described as maken, but it certainly included the installation of a set of 22 new pipes and a register called tbaerdoenken (bourdon), an organ stop with a low pitch and a characteristic dark, droning tone. Niehoff's high wage of 108 Karolusgulden is indicative of the extent of his work. ${ }^{91}$

This marked interest in religious music in the parish liturgy was a broader phenomenon around the middle of the century. Scholars have noted how, after the Protestant criticisms, there was a revival of the ancient concept of music as praise to God around 156o, and the sudden celebration of Saint Cecilia is a particularly apt expression of that trend. Cecilia had been associated with music from at least the fifteenth century onwards; she was usually represented with instruments such as a viola or a portative organ. Around the middle of the sixteenth century, however, she would take on the role of the patron saint of church music. ${ }^{92}$ In the middle of the sixteenth century liturgical celebrations of Saint Cecilia's feast were established all around the Low Countries too, for example in Wezemaal's church of Saint Martin in $1563 .{ }^{93}$ Her popularity was also reflected in paintings, such as a popular composition by Michiel Coxcie (c. 1499-1595). Multiple copies exist, some still in Netherlandish churches, but the most famous version was bought by King Philip II in 1569 (fig. 92). Crowned with a richly inlaid diadem and accompanied by three angels, Cecilia is playing a harpsichord. The heavenly group is performing music from three clearly legible printed music books, which have been identified as Petrus Phalesius' 1559 edition of motets written by Jacob Clemens non Papa (c. 1510-c. 1555). In fact, the group is singing a polyphonic, four-part piece entitled Cecilia virgo gloriosa, an ode to this very saint. ${ }^{94}$ Common to all versions is the key figure of the angel looking straight to the viewer, holding up the clearly legible notes and text of the ode, thus inviting sixteenth-century observers to join them in their praise for Saint Cecilia.

Musicologists have recently postulated a causal connection between the Protestant demands for simplicity, and vernacular, 
congregational plainchant on the one hand, and the musical elaboration and its increasing ornamentation in the Roman liturgy on the other. In this context, Eric Rice has studied liturgical changes in the 1570 os in Aachen Cathedral. One of his arguments was that, in the liturgy for Charlemagne, the alteration of traditional plainchant melodies into a polyphonic setting was a direct reaction to the Reformation. This new musical treatment was supposed to add both ornament and rhetorical power to the services. ${ }^{95}$ Most recently, Stefanie Beghein has similarly described church music as a tool of confessionalization in the later sixteenth and early seventeenth century. Studying the musical culture in the Antwerp parish churches during the Counter-Reformation, she found an increased attention

\section{FIGURE 92}

Michiel Coxcie, Saint Cecilia, c. 156o-1569, Madrid, Museo del Prado

(C) MUSEO DEL PRADO

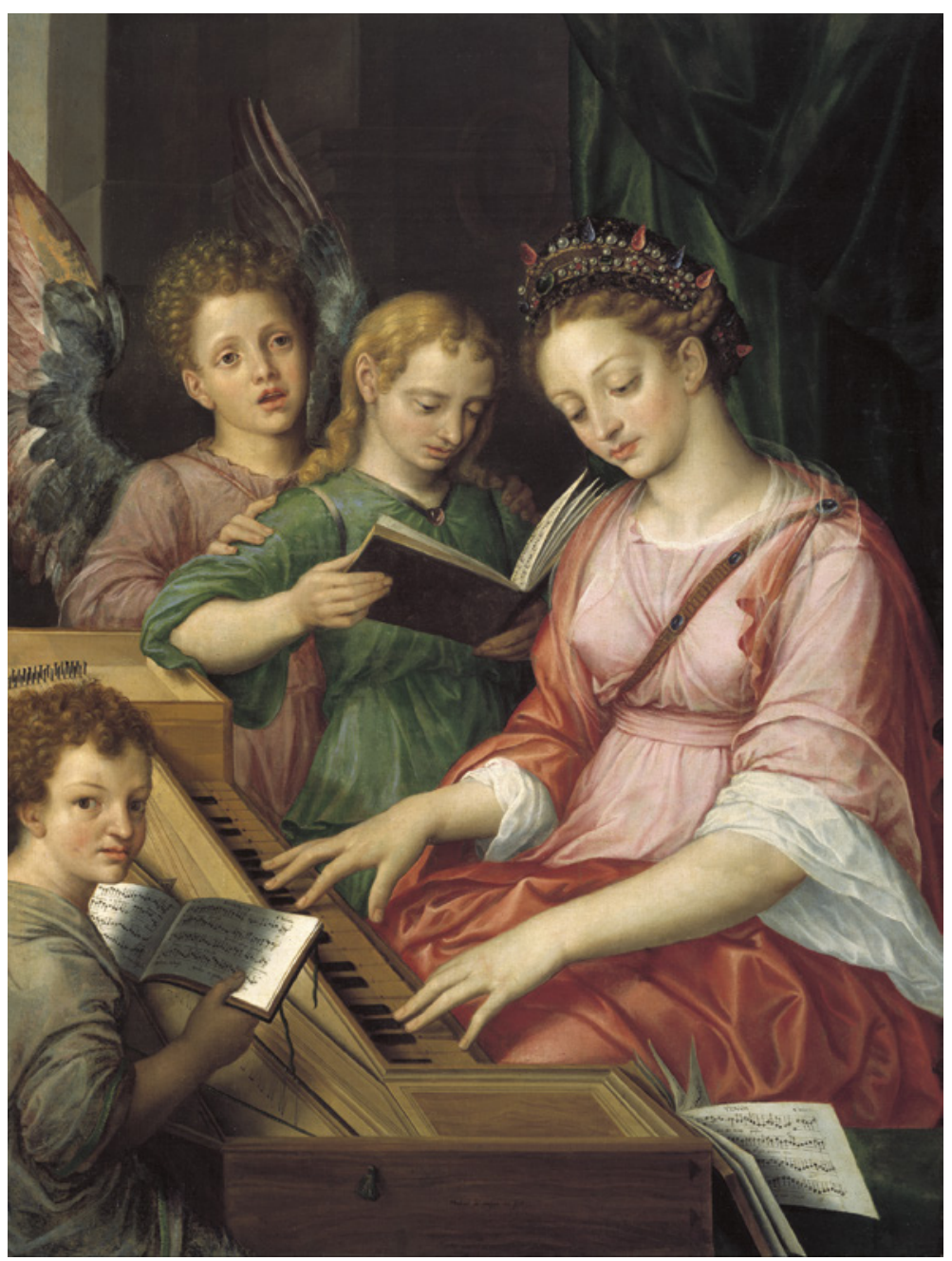


for professional and polyphonic music, exemplified by increasing expenses related to musical performances during parish services. This was but one expression of a general policy that attached renewed importance to the embellishment of the parochial liturgy. Beghein interpreted this as Catholic self-representation, in contrast to the simple, unaccompanied congregational plainchant in Protestant services. Hence, music was used to articulate confessional differences, and by increasing both the quality and frequency of musical performances, it was hoped that this would also make the services more attractive and so strengthen the people's devotion. ${ }^{96}$

The source material from Zoutleeuw around the middle of the century clearly suggests something very similar. However, there is mostly no information about the actors behind these initiatives at our disposal, let alone on their precise motivations. Therefore, such a reading would never be more than speculation, were it not for the fact that the discussed phenomena of adding ornament and rhetorical power also occur in the patronage for the church in those same years, in which Floris' magnificent sacrament house functioned as monumental centerpiece. Hence, the next chapter presents a contextual reading of these private patronage projects, clearing the ground for firmer conclusions on both the initiators and the motivations at play. 